\title{
低線量放射線の生体影響
}

小島周二

\section{Effect of Ionizing Radiation on the Living Body}

\author{
Shuji Kojima \\ Department of Radiation Biosciences, Faculty of Pharmaceutical Sciences, Tokyo University \\ of Science $(T U S) ; 2641$ Yamazaki, Noda, Chiba 278-8510, Japan.
}

(Received August 27, 2013)

\begin{abstract}
Since the Fukushima nuclear plant accident following the great East Japan earthquake on March 11, 2011, we have been warned to be careful about possible radiation exposure almost every day in newspapers and on TV. Radioactive iodine $\left({ }^{131} \mathrm{I}\right)$ and cesium $\left({ }^{134} \mathrm{Cs},{ }^{137} \mathrm{Cs}\right)$ produced by nuclear reactions were released into the air during and after the accident, and have been scattered by the winds in Tohoku and in the Kanto district. Even today, 2 years after the accident, there is great public concern about possible pollution of foodstuffs and fishery products with radioactive cesium, not only in Japan, but also in other countries. On the other hand, decontamination work has been proceeding, including removal of contaminated soil near the accident site. Since the accident, many media reports have continued to tell us only that current dose levels of radiation are not dangerous to human health. But, many people are not satisfied with such vague statements, and want to understand the situation in more detail. So, it is important to provide basic education about the effects of radiation to the general public. I am a professor of the Department of Radiation Biosciences at Tokyo University of Science, and so I am very familiar with radiation and its dangers. So, in my lecture today, we would like to explain the effects of radiation and put the present situation into perspective, so that people will better understand the risks, and not be unnecessarily afraid.
\end{abstract}

Key words_— radiation effect; living body; contamination; minimum dose

\section{1.はじめに}

今まさに“放射線を正しく理解し，正しく怖がる” というフレーズが日本国民に求められている，とい うのは, 2011 年 3 月 11 日に起きた東日本大震災に より，福島原子力発電所も大きな被害を受け，原子 炉の冷却装置が停止，その後復旧に向けての作業が 行われつつあるものの，今日なおわが国のみならず 世界各国にも恐怖心を与えている現状があるからで ある．原発事故発生に伴い，核反応により生成され た放射性ヨード $\left({ }^{131} \mathrm{I}\right)$ やセシウム $\left({ }^{134} \mathrm{Cs},{ }^{137} \mathrm{Cs}\right)$ が東北・関東地方に飛散，その後の降雨により地上 に落下, 露地野菜や水道水等に混入, 日常生活がパ ニックに陥る事態にまでに至った。一般人の多く は，「“放射線は得体の知れない怖いもの”であり,

The author declares no conflict of interest.

東京理科大学大学院薬学研究科（T278-8510 千葉県野 田市山崎 2641)

e-mail: kjma@rs.noda.tus.ac.jp

本総説は, 日本薬学会第 133 年会シンポジウム S30301 で発表した内容を中心に記述したものである.
これにあたれば即死する，また死に至らない場合で も数年後にはがんを患い，死んでしまう」と考えて しまうようである。事故後 2 年を経過した現在，陸 地での放射線量は低下したにもかかわらず，放射性 セシウムによる野菜類の污染や風評に怯えている人 もいる．放射科学を担当してきた私自身も，原発事 故がよもやわが国で起こるということは想像もしな かった。一方で，今回の事故により，わが国の放射 線（能）に関する基礎教育の重要性を改めて思い知 らされた。これまでのテレビを始め多くのマスコミ の報道内容の多くは，“現在の放射線量は健康にな んら影響がありません!”のみであり，一般の方々 が安心できないのは当然である。本シンポジウムで は原発事故に伴う環境の放射能污染による人体影響 を私自身の研究結果と過去のチェルノブイリ原発事 故及び長崎・広島原爆被ばく調査報告等を示すこと により，読者の皆様が多少なりとも放射線に対する 恐怖を払拭できる一助になれば幸いである。 


\section{2. 線量限度設定の手順}

国際放射線防護委員会 (International Commission on Radiological Protection; ICRP) は職業上, 放射線を取扱う「業務従事者」や「一般公衆」に対 して，以下の概念の下，被ばくの上限值を線量限度 として各国へ勧告している.

1）急性の放射線障害（確定的影響に分類）の発 生を防止するため，しきい線量（影響があらわれ る最低の線量）よりも十分低く定める.

2）がんと遺伝的影響（確率的影響に分類）の発 生率については，しきい線量がないと仮定した上 で，一般社会で容認できる程度の被ばく線量を設 定する.

わが国では放射線障害防止法にこの勧告を取り入 れ，線量限度として一定期間において以下の值を超 えてはならないと規定している.

(1) 業務従事の線量限度； 5 年間 $<100 \mathrm{mSv}$ (平 均 $20 \mathrm{mS} / \mathrm{y})$. ただし, いかなる 1 年も $<50 \mathrm{mSv}$

(2) 業務従事の緊急時線量限度 ; 作業期間 $<100$ $\mathrm{mSv} \rightarrow 250 \mathrm{mSv}$ （事故当初の暫定值）

(3) 公衆の線量限度 ; 1 年間 $<1 \mathrm{mSv}$

これら線量限度うち，(1)の業務従事の線量限度は 以下の手順で決定され，ICRP1990 勧告として各国 に通達された。

「年線量限度として，10, 20, 30 及び $50 \mathrm{mSv}$ を選 択し，放射線被ばくによる死亡確率の発現年齢分 布を作成した場合，年齢別の相乗的死亡確率（生 涯全死亡率に対する放射線の寄与する割合）が放 射線被ばくにより増加するが，線量限度を“受け 入れ不能レベルの下限值”であり，“我慢できる レベルの上限值”で決めるべきである. ただし， 年齢別死亡確率は 65 歳までで $1 \times 10^{-3}$ 以下と設 定する」

この結果，業務従事者の場合（就業期間を 18 歳 から 65 歳までとする), 一様に連続して被ばくする と仮定すると， 65 歳までの年齢別死亡率が $1 \times 10^{-3}$
以下となるのは, $20 \mathrm{mSv} /$ 年 (平均余命短縮 0.5 年, 死亡確率 $=3.6$, 生涯線量 $=1.0 \mathrm{~Sv})$ の線量である. しかし, 生涯線量のみで被ばく管理をした場合, 短 期間に生涯線量の $1.0 \mathrm{~Sv}$ を超えてしまうこともあ り，また管理にある程度の融通性を持たせることも 考慮し,

「5 年間で $100 \mathrm{mSv}$ ，ただし，いかなる 1 年間で も50 mSv を超えてはならない」

と決められた。なお，緊急時は作業期間中（短期 間）で $100 \mathrm{mSv}$ と線量限度を定めているが，福島 原発事故当初は $250 \mathrm{mSv}$ までこの限度が上げられ た.

\section{3. 生体は何グレイから放射線を感知するか？} 動物実験からの推定線量

先に述べたように ICRP の勧告に基づき，わが国 では放射線を職務上取り扱う者（放射線業務従事者 という）に対しては 5 年間で $100 \mathrm{mSv}(20 \mathrm{mSv} /$ 年 $)$ 以下で，いかなる 1 年間も $50 \mathrm{mSv}$ を超えてはなら ず，一般公衆に対しては 1 年間で $1 \mathrm{mSv}$ を超えて はならないと規定している。はたして，ヒトの体が 感じとれる線量は何 Sv なのか，感じとれなければ いかなる影響も発生しないことになることから，細 胞が感じ得る最低線量を知る必要がある。放射線は ご存知の通り細胞に酸化ストレスを与える。そこ で，私達の研究室では放射線暴露後の DNA 損傷修 復初期にみられる epidermal growth factor receptor (EGFR) の細胞内核フォーカス形成をヒト肺がん 細胞 A549 を用いて検討し，細胞が放射線を感じと れる急性被ばくによる最低線量を推定した。この結 果, $50 \mathrm{mGy}(\mathrm{mSv})$ 以上の $\gamma$ 線の線量で有意なフ オーカス形成がみられた [Fig. 1(A)]。また，酸化 ストレスに応答し，核移行することが知られている 転写因子 nuclear factor erythroid-derived 2-related factor 2 (Nrf2) の応答性を放射線高感受性マウス マクロファージ様細胞 RAW264.7 で検討すると,

$0.1 \mathrm{~Gy}(100 \mathrm{mGy} / \mathrm{Sv})$ 以上から有意な核移行がみ

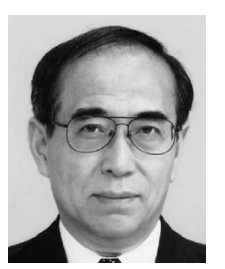

小島周二

1948 年 10 月 28 日神奈川県横浜市生. 1975 年千葉大学大学院薬学研究科修士課程修了. 帝京大学薬学 部助手, 講師を経て, 1989 年に東京理科大学生命科学研究所に講師として赴任, 助教授, 2001 年 4 月 1 日に東京理科大学薬学部教授（放射線生命科学）に就任し，現在に至る。がん関連抗体を用いたがんの 放射免疫学的診断と治療, 生体内プテリン化合物の抗酸化活性, 低線量放射線に対する生体の適応応答 に関する研究，放射線影響での細胞間シグナル伝達分子としてのATP の役割等の研究を行う．科学技 術庁長官賞（放射線安全管理）受賞. 大学等放射線施設協議会理事. 放射線計測協会理事. 日本アイソ トープ協会広報誌「Isotope News」誌集委員長. 日本アイソトープ協会学術諮問委員など．趣味：ジョ ギング，料理，一木彫，川柳・詩作など. 
(A) Formation of EGFR in nuclear

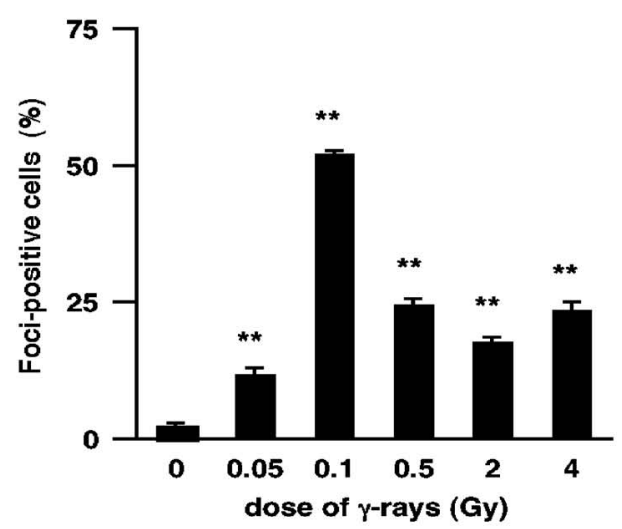

(B) Translocation of Nrf2 into nuclear

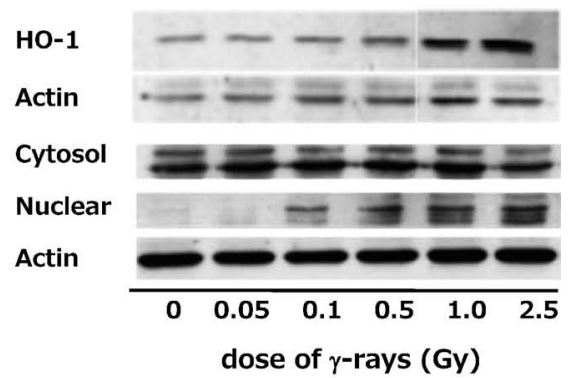

Fig. 1. Effect of Dose on the Formation of EGFR Focus in Nuclear of Human Lung Cancer Cell A549 (A) and the Translocation of Nrf2 to Nuclear of Mouse Macrophage-like RAW264.7 Cells (B)

(A) **Significantly different from 0 Gy group at $p<0.01$. Modified from Tamaishi et al., Radiat. Res., 175, 193-200 (2011). (B) Modified from Tsukimoto et al., J. Radiat. Res., 51, 349-353 (2010).

られ，本因子により制御される抗酸化タンパク質 heme oxygenase-1 (HO-1) も同一線量から誘導さ れた [Fig. 1(B)]. 1,2)

ヒトの放射線に対する感受性がマウスより 2 倍程 高いことから，放射線業務従事者の 1 年間の線量限 度として $50 \mathrm{mSv}$ は妥当であると言えよう。

さて，放射線の被ばく線量と生体影響（障害の発 生）はごのようになっているのだろうか？ よく知 られているように，100-250 mSv を境としてこの線 領域を超えると線量に応じて，遺伝的影響，発が 几, 奇形・知的障害等の晚発性障害，さらに線量が 高くなると骨髄障害に起因する白血球の減少，そし て数十 Sv 以上では腸管死等の急性障害が発生す る。これら生体影響の中で，がんの発生に関しては 他の遺伝的影響と同様，「線量に依存して発症のリ スクは高まる（直線閾值なしの仮説 $=\mathrm{LNT}$ 仮説）」 とされてきたが，境界線量（100-250 mSv）以下の 線量でも当てはまるか否かは今でもなお不明であ り, 放射線生物学分野で世界の研究者が物議を交わ している.

では，低線量域での放射線の生体影響をどのよう に考えたらよいのであろうか? 放射線を感知した 生体ではその線量にかかわらず，生体にとつて「害 のある効果 (障害 ; Negative effect)」と「有益な効 果（適応応答/防御；Positive effect）」が同時に発 生，両者のバランス，すなわち「障害と防御」の “大きさの差”が生体影響となって出現すると考え られる（Fig. 2)。実際の現象で説明する．Priming
/Adapting/Conditioning dose と呼ばれる低線量の 放射線をあらかじめ照射しておき，その後 Challenging dose と呼ばれる致死線量の放射線を照射し た際，生存率が高められる現象は「放射線抵抗性の 誘導」と呼ばれている。この現象は 0.5-1 Gy の線 量域でみられ，DNA 損傷とその後の修復系の誘導 が起こることによりあらわれると考えられてい る. ${ }^{3)}$ すなわち，放射線によって DNA の二重鎖切 断が生ずると, 切断部位で ataxia telangiectasia mutated（ATM）が活性化し，ヒストン H2AXがリン 酸化 phosphorylated histone variant $\mathrm{H} 2 \mathrm{AX}(\gamma \mathrm{H} 2 \mathrm{AX})$ される，さらに，その部位に tumor suppressor p53binding protein 1 (53BP1) などの修復タンパク質が 集積し，最終的に二重鎖切断が修復されることでこ の抵抗性が誘導される. ${ }^{4)}$ なお，二重鎖切断後の修 復系としては主として相同組換え（homologous recombination; HR）と非相同末端融合（non-homologous-end-joining; NHEJ) が知られているが, 最近低線量の X 線照射によりDNA リン酸化酵素 （DNA-PKcs）の活性化を介して，NHEJ が誘導さ れることで「放射線抵抗性の誘導」があらわれるこ とが明らかとなった. ${ }^{5)}$ 一方，1 Gy 以上では放射線 による損傷量が修復量を上回るために細胞死に至る という結論である。私達の研究室でもごく最近，低 線量の $\gamma$ 線照射により DNA 二重鎖損傷と細胞から のエネルギー供与体と知られている ATP が放出, その後この ATP が細胞膜に存在する受容体（P2 受容体）の活性化を介して $\gamma \mathrm{H} 2 \mathrm{AX}, 53 \mathrm{BP} 1$ 及び 
ATM の Focus を形成し，DNA 損傷が修復される という新規「放射線抵抗性の誘導」メカニズムを明 らかにしている.6)

これらの報告より，100-250 $\mathrm{mSv}$ 以下の低線量域 での放射線の生体影響では，「障害」よりも「適応 応答/防御」が優位にあらわれるものと思われるが, 低線量・低線量率の放射線被ばくががん等の遺伝的 影響につながらないという確証は今日まで皆無であ り, 今後詳細な研究結果が必要であろう.

4. チェルノブイリ原発事故による小児甲状腺が ん発症に関する調査報告から

1986 年 4 月 26 日に旧ソ連 (現ウクライナ共和国) のチェルノブイリ原子力発電所 4 号炉がメルトダウ ンを起こし爆発，大量の放射性物質が環境中に放出 された，その後，今日までに種々の調査が行われ， これまでに明らかとなっている健康影響は事故当初 に環境中に放出されたヨウ素 $131\left({ }^{131} \mathrm{I}\right)$ による小 児甲状腺がんの発症である. ${ }^{7)}$ ベラルーシのゴメリ

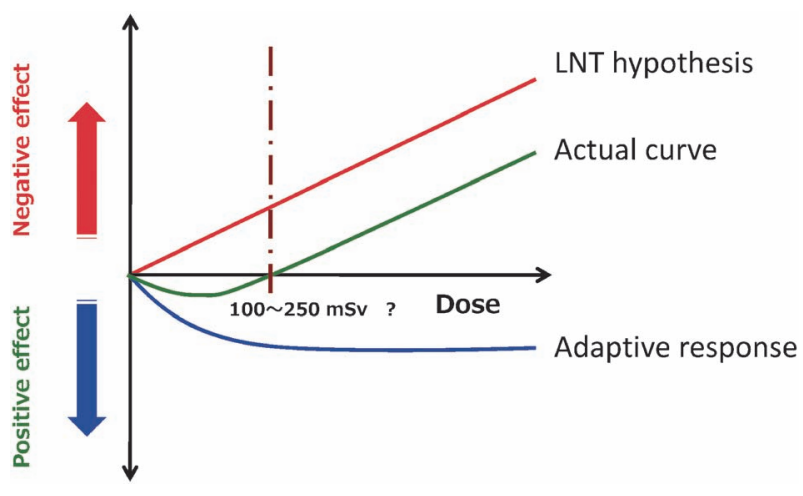

Fig. 2. Prospective Influence Curve (PIC) of Ionizing Radiation on the Living Body
污染地区では事故 5-8 年後で甲状腺がんの罹患率は それ以前の 5 年間と比較して 10 倍程も高くなって いる [Fig. 3(A)]。ささらに，甲状腺がんの発症数を 年齢別に比較すると，事故当時 1 歳未満であった乳 幼児に多発し, 被ばく線量は $2 \mathrm{~Sv}$ 以上である [Fig. 3(B) ]。この背景としては, 原発事故後牛乳などに 含まれた ${ }^{131} \mathrm{I}$ の体内摂取により，短期間で $100 \mathrm{mSv}$ 以上を被ばくしたものと思われる（乳幼児の放射線 感受性が成人の 2 倍と仮定して)。また，短期間で 数 $10 \mathrm{mSv}$ (平均 $40 \mathrm{mSv}$ ）以上被ばくしたために子 供（1 歳未満-3 歳）の甲状腺がん罹患率が増加した ものと思われる。

わが国で 2011 年 3 月 11 日に起こつた福島原発事 故も規模は異なるものの，メルトダウンによる爆発 により主として ${ }^{131} \mathrm{I},{ }^{137} \mathrm{Cs},{ }^{134} \mathrm{Cs}$ が，大気中に放出 され，東北・関東地方に深刻な放射能污染をもたら した．その後，わが国を始め諸外国の研究者や関連 委員会により福島県内外住民の全身と甲状腺の被ば く線量が推定された。 2013 年 5 月 26 日公開された 国連科学委員会の報告案によると, 福島県民の事故 後 1 年の甲状腺の被ばく線量は, 原発 $30 \mathrm{~km}$ 圏外 の成人が 8-24 mSv，1 歳児は 33-66 mSv, $30 \mathrm{~km}$ 圏 内の 1 歳児が 20-82 mSv であり，いずれもがんが 増加するとされている $100 \mathrm{mSv}$ 以下であった。ま た，集団で夕た日本国民の総被ばく線量は，甲状腺 はチェリノブイリの約 30 分の 1 （福島 9 万 9000 人 /チェルノブイイ 296 万 7000 人)，全身は約 10 分の 1 と推定している. 個人の被ばく線量については, 福島県民の多くは防護剤を摂取しなければならない 基準以下であり,「がんが増加しても非常に少なく,
(A)

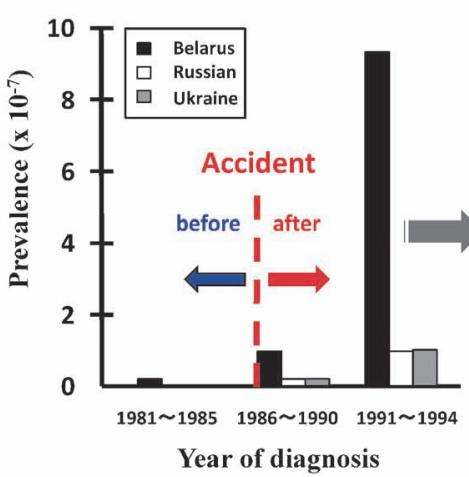

(B)

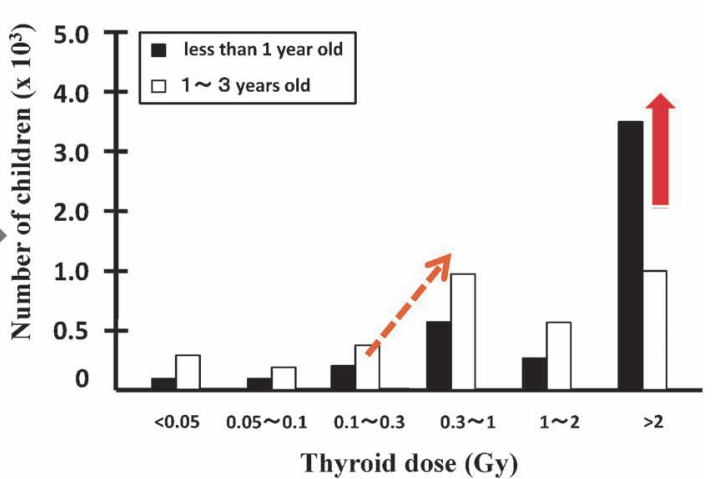

Fig. 3. Number of Diagnosed Thyroid Cancer Cases in Belarus as a Result of the Chernobyl Accident UNSCEAR Rep. 2000. 
見つけるのは困難」と結論づけている.これらの推 定值より，ベラルーシでみられたような小児甲状腺 がんの発生はないと思われるが，セシウムにより污 染された食物や牛肉の摂取による数年から数十年後 の晚発影響が一般公衆の脅威となっているのが現状 であり，行政はもちろんのこと，国民一人一人が体 内摂取の原因となる要因を確認し，これらの体内摂 取は可能なかぎり避けるべきであろう.

\section{5. 放射線影響研究所による広島・長崎原爆被ば く者の長期追跡調査報告}

広島（1945 年 8 月 6 日）及び長崎（1945 年 8 月 9 日）に原子爆弾が投下，2 年後の 1946 年には米国 により両市に, 原爆傷害調査委員会 (Atomic Bomb Casualty Commission; ABCC) が設置され，被ばく 者の健康調査が開始された。その後，1975 年に改 組され財放射線影響研究所となり，日・米両国で被 ばく者 94000 人と非被ばく者 27000 人が生涯にわた り追跡調查された。これまでの調査で分かったこと は以下の通りである。

1）がんの罹患率は，200 mSv 以上の被ばく者で 非被ばく者と比較して統計的に有意に高くなる. 30 歳から 70 歳までにがんになる人は $30 \%$ ある が，30 歳で $200 \mathrm{mSv}$ 被ばくすると $33 \% （ 1.1$ 倍） に増加する。

2）白血病の発生については，日本人では一生の うちに発症するのは 1000 人あたり 7 人である が，平均 $200 \mathrm{mSv}$ の被ばく者で 3 人増え 10 人と なる。

3）胎児への影響に関しては妊娠のステージによ り異なり, 妊娠 8-15 週で $200 \mathrm{mSv}$ 被ばくした場 合，知的障害を持つ子供の出産率が線量依存的に 増加する。16-25 週では $500 \mathrm{mSv}$ 以上から影響が あらわれる。0-7 週と 26 週以降では影響がみら れない。

5）遺伝的影響に関しては，被ばくした親から生 まれた子供の健康状態は，非被ばく者の親から生 まれた子供と変わらない。

\section{6. 環境科学技術研究所による低線量率 $\gamma$ 線長期} 間照射のマウスへの影響調査報告

福島第一原発事故後の人体影響で問題となるのは 半減期の長い ${ }^{137} \mathrm{Cs}$ (30 年) による慢性被ばくによ る晚発性障害である。この障害発生の有無が明らか になるには数年から数十年の年月を要し，また予測
することも非常に困難である，そこで，公益財団法 人環境科学技術研究所で行われたマウスを用いた長 期（平成 16-25 年度の 10 年間）に渡る低線量率 $\gamma$ 線の連続照射調査研究報告（平成 23 年 10 月）を紹 介する.

この調査研究では, $909 \mu \mathrm{Gy} / \mathrm{h}$ (総線量 $8000 \mathrm{mGy}$ ), $45 \mu \mathrm{Gy} / \mathrm{h}$ （総線量 $400 \mathrm{mGy），及び} 2.3 \mu \mathrm{Gy} / \mathrm{h}$ （総 線量 $20 \mathrm{mGy}$ ）の 3 群の低線量率 $\gamma$ 線環境下で 1 日 20 時間，延べ 400 日間雌雄のマウスを飼育し，雌 雄親世代, 仔（F1）, 及び孫（F2）の体重，寿命， 出産数, がん発生染色体異常の発生率等を非照射群 と比較検討した。平成 23 年 10 月に公開された調査 研究結果報告での「寿命・死因・がん発生等の解析」 に関するものは以下の通りである.

(1) 交配実験では，909 $\mu \mathrm{Gy} / \mathrm{h}$ （総線量 8000 mGy）群の親世代で, 非照射群や他の照射群と 比較して, 出産数, 及び離乳数に有意な減少がみ られた $(p<0.05)$.

一方，仔（F1）世代では交配実験では有意な 差はみられなかった。

(2) 体重については，909 $\mu \mathrm{Gy} / \mathrm{h}$ （総線量 8000 mGy）群の仔（F1）世代雄マウスで, 非照射群 と比較して，64-80 週齢の期間で有意な体重の増 加がみられた $(p<0.05)$ ，一方，親世代雄及び仔 （F1）世代雌雄マウスでは，いずれの実験群と比 較して，有意な差はみられなかった。

(3) 寿命に関しては，909 $\mu \mathrm{Gy} / \mathrm{h}$ （総線量 8000 $\mathrm{mGy})$ 群の親世代雄マウス $(p<0.002)$ 及び仔 （F1）世代雄マウス $(p<0.02)$ で，非照射群と 比較して有意な寿命の短縮がみられた。一方，孫 （F2）マウスでは，雌雄ともに非照射群と比較し て寿命に有意な差はみられなかった。

(4) 死因, がん病変の種類及び発生率等に関して は，親世代，仔（F1）世代，及び孫（F2）世代 すべてについて，実験群間で有意な差はみられな かった (Table 1).8,9)

これらの結果, 及びヒトの放射線感受性がマウス の約 2 倍であること，また子供の感受性が成人の 2 -5 倍であることを考慮し, 福島原発事故後の子供 の晚発性障害を推定すると，これまでに報告されて いる被ばく線量（線量率と実効線量）ではなんら影 響はないと思われる。 
Table 1. Transgenerational Eeffects in Male and Female Mice Exposed to Continuous Low-dose-rate $\gamma$-Rays

\begin{tabular}{|c|c|c|c|c|c|c|c|}
\hline \multirow{2}{*}{ Dose rate } & \multirow{2}{*}{ Total dose } & \multirow{2}{*}{ No. of delivery } & \multirow{2}{*}{ Lifespan } & \multirow{2}{*}{ Cancer } & \multicolumn{3}{|c|}{ Child (F1)/Grandchild (F2) } \\
\hline & & & & & No. of delivery & Lifespan & Cancer \\
\hline $\begin{array}{c}21 \mathrm{mGy} / \mathrm{d} \\
(909 \mu \mathrm{Gy} / \mathrm{h})\end{array}$ & $\begin{array}{r}8000 \text { mGy } \\
(400 \mathrm{~d})\end{array}$ & $\begin{array}{c}\downarrow \\
(p<0.05)\end{array}$ & $\begin{array}{c}\downarrow \\
\left(\sigma^{\nearrow}, p<0.002\right)\end{array}$ & \pm & \pm & $\begin{array}{c}\downarrow \\
\left(\sigma^{\urcorner}, p<0.02\right)\end{array}$ & \pm \\
\hline $\begin{array}{l}1.1 \mathrm{mGy} / \mathrm{d} \\
(45 \mu \mathrm{Gy} / \mathrm{h})\end{array}$ & $\begin{array}{r}400 \text { mGy } \\
(400 \mathrm{~d})\end{array}$ & \pm & $\begin{array}{c}\downarrow \\
(\text { 우 }, p<0.05)\end{array}$ & \pm & \pm & \pm & \pm \\
\hline $\begin{array}{l}0.05 \mathrm{mGy} / \mathrm{d} \\
(2.3 \mu \mathrm{Gy} / \mathrm{h})\end{array}$ & $\begin{array}{c}20 \text { mGy } \\
(400 \mathrm{~d})\end{array}$ & \pm & \pm & \pm & \pm & \pm & \pm \\
\hline
\end{tabular}

$\downarrow$, Significantly deceased $v s$. healthy control. \pm , Not significantly altered $v s$. healthy control. Tanaka S. et al., Radiat. Res., 160, 376-379 (2003). Modified from Tanaka IB 3rd. et al., Radiat. Res., 167, 417-437 (2007).

\section{7. おわりに}

福島第一原発事故に伴う ${ }^{131} \mathrm{I}$ や ${ }^{137} \mathrm{Cs}$ 等による環 境污染による人体への影響に関しては，これまでの 動物実験，チェルノブイリ及び広島・長崎原爆被ば く者の長期調査報告より以下のことが言える.

1）細胞やマウスを用いた実験データより

(1) ヒト細胞が放射線を感知できる線量は 1 回 照射（急性被ばく）の場合で，数 $10 \mathrm{mGy}(\mathrm{Sv})$ 以上である。

(2) 同一線量でも，長期間の被ばく（慢性被ば

く）と短期間の被ばく（急性被ばく）ではあら われる生体影響は異なり，前者の影響は後者の 影響の 1/5-1/2 であろう。なお，ICRP による DDREF は 2 である.

(3) 慢性被ばくでは, 約 $1000 \mu \mathrm{Sv} / \mathrm{h}$ 以上で, かつ総線量が数 Gy を超えると身体的及び遺伝 的（F1\& F2）影響があらわれる.

2）長期間でのヒト被ばく統計データより

(1) ヒトでは $200 \mathrm{mSv}$ 以上の被ばく（おそら く急性被ばく）で，発がんリスクが有意に高く なる。

(2) 妊婦に対しては, 妊娠 8-15 週で $200 \mathrm{mSv}$ 以上の被ばくで，胎児への影響があらわれる可 能性がある。妊娠 16-25 週では, $500 \mathrm{mSv}$ 以上 で発育不全等の障害が発生する可能性がある.

(3) 1 歳未満の乳幼児でも甲状腺に, 事故後の 急性被ばくで $100 \mathrm{mSv}$ 以上（乳幼児の放射線 感受性が成人の 2 倍と仮定）被ばくすると甲状 腺がんを発症する可能性が高くなる.

なお，Brenner らによって既に医療被ばくによる 線量とがんの発生については報告されており，有意
にがんリスクを増加させる $\mathrm{X}$ 線又は $\gamma$ 線の最低線 量は急性被ばくで，約 10-50 mSv ということであ り,10) 私達がヒト細胞実験報告したものとほぼ同線 量である。

以上，動物を用いた実験結果と過去のチェルノブ イリ原発事故及び長崎・広島原爆被ばく調査報告を 提示させて頂いた．参加者の皆様が十分理解され， 安心の一助になれば幸いである。

謝辞本研究を遂行するに当たり共同研究者の 月本光俊助教を始め, 東京理科大学大学院薬学研究 科小島研究室の大学院生諸君にこの場を借りて深く 御礼申し上げます。

\section{REFERENCES}

1) Tamaishi N., Tsukimoto M., Kojima S., Radiat. Res., 175, 193-200 (2011).

2) Tsukimoto M., Tamaishi N., Homma T., Kojima S., J. Radiat. Res., 51, 349-353 (2010) .

3) Joiner M. C., Marples B., Lambin P., Short S. C., Turesson I., Int. J. Radiat. Oncol. Biol. Phys., 49, 379-389 (2001).

4) Bekker-Jensen S., Mailand N., DNA Repair, 9, 1219-1228 (2010).

5) Yu X., Wang H., Wang P., Chen B. P. C., Wang Y., J. Cell. Physiol., 226, 369-374 (2011).

6) Nishimaki N., Tsukimoto M., Kitami A., Kojima S., DNA Repair, 11, 657-665 (2012).

7) United Nations Scientific Committee on the Effects of Atomic Radiation (UNSCEAR) 2000 report Vol. II. Effects; Sources and 
Effects of Ionizing Radiation.

8) Tanaka S., Tanaka I. B. III, Sasagawa S., Ichinohe K., Takabatake T., Matsushita S., Matsumoto T., Otsu H., Sato F., Radiat. Res., 160, 376-379 (2003).

9) Tanaka I. B. III, Tanaka S., Ichinohe K., Matsushita S., Matsumoto T., Otsu H., Oghiso Y., Sato F., Radiat. Res., 167, 417-437
(2007).

10) Brenner D. J., Doll R., Goodhead D. T., Hall E. J., Land C. E., Litte J. B., Lubin J. H., Preston D. L., Preston J., Puskin J. S., Ron E., Sachs R. K., Samer J. M., Setlow R. B., Zaider M., Proc. Natl. Acad. Sci. USA, 100, 1361-1376 (2003). 